\title{
Anticancer effects of the flavonoid diosmetin on cell cycle progression and proliferation of MDA-MB 468 breast cancer cells due to CYP1 activation
}

\author{
VASILIS P. ANDROUTSOPOULOS, SACHIN MAHALE, RANDOLPH R.J. ARROO and GERRY POTTER
}

Leicester School of Pharmacy, De Montfort University, The Gateway, Leicester, LE1 9BH, UK

Received November 25, 2008; Accepted January 2, 2009

DOI: $10.3892 /$ or_00000384

\begin{abstract}
Flavonoids constitute a large class of polyphenolic compounds with cancer preventative properties. We have examined the ability of the natural flavone diosmetin to inhibit proliferation of breast adenocarcinoma MDA-MB 468 and normal breast MCF-10A cells and found that this compound is selective for the cancer cells with slight toxicity in the normal breast cells. Diosmetin was metabolised to the structurally similar flavone luteolin in MDA-MB 468 cells, whereas no metabolism was seen in MCF-10A cells. Diosmetin caused $\mathrm{G}_{1}$ arrest at $10 \mu \mathrm{M}$ in MDA-MB 468 cells after 48-h treatment whereas this effect was not observed in MCF-10A cells. We suggest that diosmetin exerts cytostatic effects in MDA-MB 468 cells, due to CYP1A1 and CYP1B1 catalyzed conversion to the flavone luteolin.
\end{abstract}

\section{Introduction}

Flavonoids are polyphenolic compounds present in plants with multiple modes of anticancer activity. Their chemopreventative properties have been explained, amongst others, by their ability to scavenge free radicals, induce apoptosis and inhibit cell signalling (1-3). A more detailed investigation of their versatile activity in cancer prevention has recently revealed a novel mechanism of action in cancer cell line models. Flavonoids such as eupatorin, daidzein and the stilbene resveratrol have been shown to be further activated to cytostatic and cytotoxic agents by the cytochrome P450 enzymes CYP1A1 and CYP1B1 (4-6). The differential expression of

Correspondence to: Dr Randolph R.J. Arroo, Leicester School of Pharmacy, De Montfort University, The Gateway, Leicester, LE1 9BH, UK

E-mail: rrjarroo@dmu.ac.uk

Abbreviations: CDK, cyclin dependent kinase; CYP, cytochrome P450; DMBA, dimethylbenzanthracene; EGFR, epidermal growth factor receptor; EROD, 7-ethoxy resorufin- $O$-deethylase; MTT, 3(4,5-dimethylthiazol-2-yl)-2,5diphenyltetrazolium bromide; TCDD, 2,3,7,8-tetrachlorodibenzo- $p$-dioxin

Key words: antiproliferative activity, cell cycle arrest, CYP1 enzymes, diosmetin, luteolin
CYP1 enzymes in cancer cells has been proposed before as a target for cancer therapy (7). As a result flavonoids which are CYP1 substrates can in theory inhibit tumor growth, while sparing normal tissue.

Diosmetin is a flavone which is present in plants belonging to the genus Teucrium (Lamiaceae) and in Portuguese olive leafs $(8,9)$. A recent study from our group has identified diosmetin as a CYP1 substrate (10). Metabolism of this compound in human breast adenocarcinoma MCF-7 cells, preinduced with the potent CYP1 inducer TCDD, caused enhanced inhibition of cell proliferation (10). In this pilot study the metabolism of diosmetin in human breast adenocarcinoma MDA-MB 468 cells is reported. The antiproliferative activity of diosmetin is further examined in MDA-MB 468 and normal breast MCF-10A cells, as well as the effect of the compound on cell cycle progression. The data suggest that diosmetin selectively inhibits the proliferation and cell cycle progression of MDA-MB 468 cells, as a result of CYP1 enzyme mediated metabolism.

\section{Materials and methods}

Materials. Diosmetin was obtained from Indofine and luteolin from Lancaster (Heysham, Lancashire, UK). Salicylamide, propidium iodide, PBS, MTT, RNase were from Sigma (Poole, Dorset, UK) and HPLC grade acetonitrile and methanol from Fisher Scientific (Loughborough, UK). Media and cell culture reagents were from Sigma Chemical Co.

Cell culture. MDA-MB 468 cells were maintained in RPMI1640 without phenol red, containing glutamine $(2 \mathrm{mM})$ and $10 \%(\mathrm{v} / \mathrm{v})$ heat-inactivated fetal calf serum. MCF-10A cells were maintained in DMEM at $37^{\circ} \mathrm{C}$, containing $2 \mathrm{mM}$ glutamine, $10 \%(\mathrm{v} / \mathrm{v})$ heat-inactivated fetal calf serum as above, EGF (20 ng/ml), insulin $(10 \mu \mathrm{g} / \mathrm{ml})$ and hydrocortisone (500 ng/ml). The cells were grown at $37^{\circ} \mathrm{C}, 5 \% \mathrm{CO}_{2} / 95 \%$ air and passaged using Trypsin-EDTA.

MTT assay. MDA-MB 468 or MCF-10A cells were seeded at a density of $10^{4}$ cells $/ \mathrm{ml}$ in 96 -well flat-bottomed plates. After $24 \mathrm{~h}$ the medium was removed and diosmetin was added in quadruplicate in fresh medium at different concentrations and at a final concentration of not more than $0.1 \%(\mathrm{v} / \mathrm{v})$ DMSO. The cells were allowed to grow for $96 \mathrm{~h}$ and the medium was removed. MTT $(0.4 \mathrm{mg} / \mathrm{ml})$ was added to each well for $3 \mathrm{~h}$ in 
A
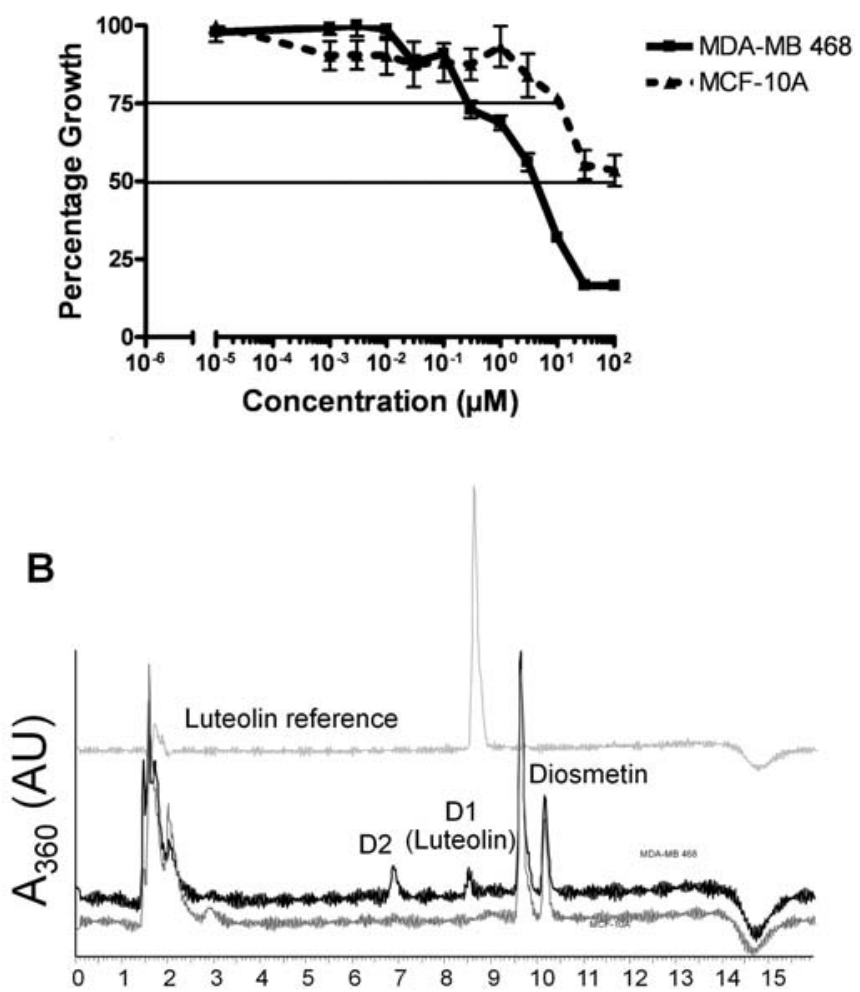

Figure 1. The bioactivation of diosmetin in MDA-MB 468 cells. (A), Cytotoxicity of diosmetin in MDA-MB 468 and MCF-10A cells. Cells were treated with different concentrations of compound for $96 \mathrm{~h}$ and cell viability was determined as described in Materials and methods. Error bars represent standard deviations for $n=4$ determinations. (B), Metabolic profile of diosmetin in MDA-MB 468 cells. MDA-MB 468 (grey) or MCF-10A (black) cells were incubated with diosmetin for $45 \mathrm{~min}$ and the samples analysed by HPLC. Luteolin standard was used as a reference for the identification of metabolite D1.

fresh medium. All medium was aspirated and the formazan product generated by viable cells was solubilised with DMSO $(150 \mu 1)$. Plates were shaken to dissolve MTT crystals and the absorbance at $540 \mathrm{~nm}$ determined using a Spectra Max M5/ M5 ${ }^{\mathrm{e}}$ microplate reader (Molecular Devices, Sunnyvale, USA). Results were expressed as the percentage of $100 \%$ (control) growth and the $\mathrm{IC}_{50}$ and $\mathrm{IC}_{25}$ calculated using Graphpad PRISM software. Dose range was in half $\log$ dilutions e.g. $100,30,10,3,1,0.3,0.1,0.03,0.01,0.003,0.001 \mu \mathrm{M}$.

Metabolism of diosmetin in cells. The experiment was performed as described previously (4).

DNA analysis. MCF-10A or MDA-MB 468 cells were passaged in Petri dishes at a density of $3 \times 10^{4}$ cells $/ \mathrm{ml}$ and left to grow for $24 \mathrm{~h}$. The cells were then pretreated with diosmetin or $0.1 \%$ DMSO (negative control) for $48 \mathrm{~h}$. The medium was removed and following trypsinisation cells were washed with cold PBS, fixed in $70 \%$ ethanol and stored at least $2 \mathrm{~h}$ in $-20^{\circ} \mathrm{C}$. The cells were then resuspended in propidium iodide solution ( $70 \mu \mathrm{g} / \mathrm{ml}$ in PBS) containing 13 Kunitz units of RNase and incubated for $30 \mathrm{~min}$ at $37^{\circ} \mathrm{C}$. Fluoresence of propidium iodide was measured on a FACS Beckman Coulter (Beckman Coulter, Oakley Court, Buckinghamshire, UK) flow cytometer. Calibration and laser alignment were performed using fluorescent beads and a flow check protocol, before each sample was run with all PMTs producing a $\mathrm{CV}$ of less than 2.5 in the calibration. All the parameters required for the DNA analysis protocol, such as Voltage, Peak gain, Integrated gain and Discriminator were optimised in preliminary experiments. The data obtained from each histogram were analyzed using Multicycle Analysis 2.0 software.

\section{Results}

In the present study the antiproliferative effects of diosmetin in MDA-MB 468 and MCF-10A cells were examined. Diosmetin was shown to strongly inhibit the proliferation of MDA-MB 468 cells $\left(\mathrm{IC}_{25}=0.4 \mu \mathrm{M}, \mathrm{IC}_{50} \approx 4.5 \mu \mathrm{M}\right)$ whereas it was considerably less active $\left(\mathrm{IC}_{25} \approx 12 \mu \mathrm{M}, \mathrm{IC}_{50}=100 \mu \mathrm{M}\right)$ in MCF-10A cells (Fig. 1A). Based on our previous report, a differential over-expression of CYP1A1 and CYP1B1

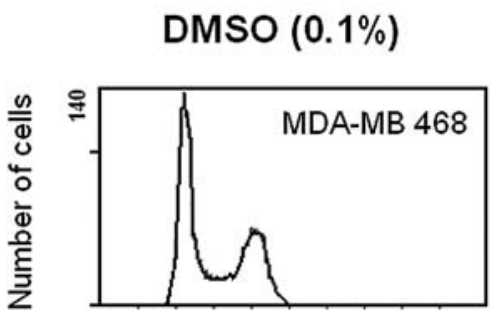

\section{Diosmetin $(10 \mu \mathrm{M})$}
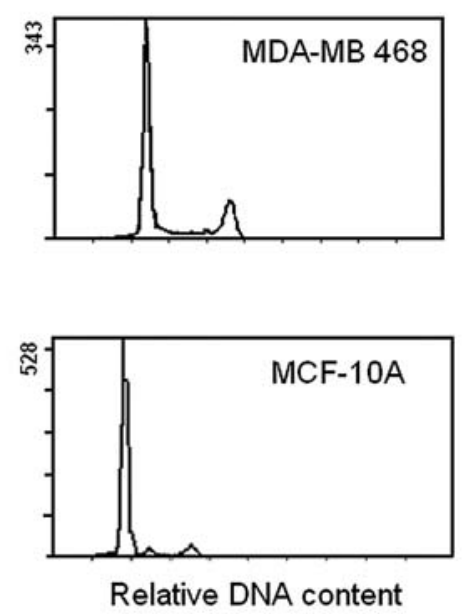

Figure 2. Cell cycle histograms of MDA-MB 468 and MCF-10A cells following $10 \mu \mathrm{M}$ treatment of diosmetin for $48 \mathrm{~h}$. The histograms are a representative trace of two independent experiments. 
A

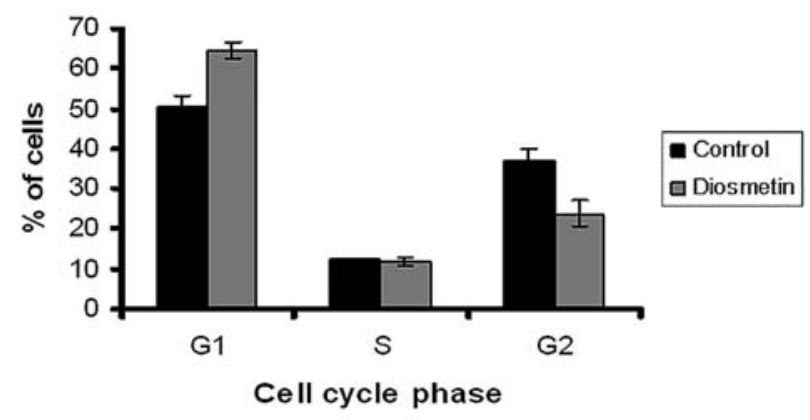

B

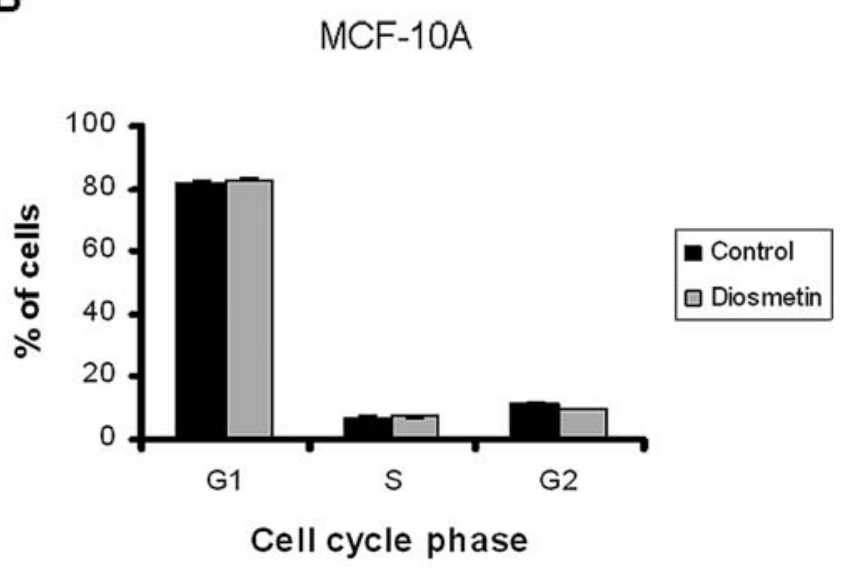

Figure 3. Percentage of cells in each phase of the cell cycle after treatment with diosmetin. MDA-MB 468 (A) or MCF-10A (B) cells were incubated with diosmetin $(10 \mu \mathrm{M})$ for $48 \mathrm{~h}$ and analysed by flow cytometry as described in Materials and methods. Error bars represent min and max values for $n=2$ determinations.

enzymes in MDA-MB 468 cells has been demonstrated (4). Thus, the hypothesis that the activation of diosmetin in the latter cell line is due to metabolism of the compound to more active species by CYP1A1 and CYP1B1, was investigated. Diosmetin was indeed metabolised to two minor products assigned D1 and D2 eluting at approximately 8.7 and $7 \mathrm{~min}$ respectively, in MDA-MB 468 cells whereas no metabolism was seen in MCF-10A cells (Fig. 1B). Luteolin (3',4',5,7 tetrahydroxy-flavone) was identified as the metabolite D1 by comparison of UV spectrum and elution profile with a luteolin reference standard (Fig. 1B). The identity of the metabolite D2 was not found, because no authentic standard corresponding to its structure was available.

In the course of investigating further the antiproliferative mechanism of action of diosmetin in MDA-MB 468 and MCF-10A cells, the compound was subjected to DNA flow cytometric analysis. Diosmetin caused $\mathrm{G}_{1}$ arrest in MDA-MB 468 cells, while no effect was seen in MCF-10A cells (Fig. 2). Specifically 48 -h treatment with $10 \mu \mathrm{M}$ diosmetin caused $13.5 \%$ of MDA-MB 468 cells to be arrested in $G_{1}$ phase of the cell cycle (Fig. 3).

\section{Discussion}

The flavonoid diosmetin is a well known chemopreventative agent with multiple modes of action. It has been demonstrated

\section{Diosmetin}<smiles>COc1ccc(-c2cc(=O)c3c(O)cc(O)cc3o2)cc1O</smiles><smiles>O=c1cc(-c2ccc(O)c(O)c2)oc2cc(O)cc(O)c12</smiles>

Luteolin

Figure 4. Chemical structures of the chemopreventative flavones diosmetin and luteolin.

to inhibit proliferation of SCC-9 human oral squamous carcinoma cells, block DMBA-induced DNA adduct formation and cytotoxicity in MCF-7 cells, as well as inhibit CYP1A1 and CYP1B1 EROD activity (11-13). According to our previous findings diosmetin was metabolized to luteolin and another unidentified metabolite by microsomes expressing human CYP1 enzymes (10). In addition luteolin was the main conversion product of the metabolism of diosmetin, in MCF-7 cells pretreated for $24 \mathrm{~h}$ with the potent CYP1 inducer TCDD (10). In agreement with these findings, the present study revealed that diosmetin is also metabolized to luteolin in MDA-MB 468 cell cultures. The metabolism enhanced the antiproliferative action of the compound, in a similar way as was previously noted in MCF-7 cells (10). A second unidentified metabolite was detected, which may have resulted from further hydroxylation of the A-ring (Fig. 4). Similar substitution patterns have been reported from CYP1B1 hydroxylation of the stilbene resveratrol (6).

Diosmetin was further shown to induce $G_{1}$ arrest of MDAMB 468 cells. We suggest that this effect is mainly due to the metabolic product of diosmetin and luteolin. The effect of luteolin on the cell cycle progression of cancer cells has been examined previously. This compound was shown to inhibit cyclin dependent kinase CDK4 and CDK2, resulting in a $\mathrm{G}_{1}$ arrest with a concominant decrease of phosphorylation of retinoblastoma protein in HT-29 human colon cancer cells, as well as inhibiting directly CDK2 in a cell free system (14). Luteolin also caused $\mathrm{G}_{1}$ arrest in OCM-1 melanoma cells through direct inhibition of CDK2 and upregulation of p27 $7^{\mathrm{KIP} 1}$ and $\mathrm{p} 21^{\mathrm{CIP} 1}$ to a lesser extent (15). Furthermore, it was shown that luteolin possesses antiproliferative activity in human hepatoma PLC/PRF/5 cells via $\mathrm{G}_{0} / \mathrm{G}_{1}$ arrest and induction of apoptosis through caspase- 3 and Bax activation (16). In addition luteolin was shown to inhibit the autophosphorylation 
of the EGFR (17). MDA-MB 468 cells express EGFR as described previously (18). $G_{1}$ arrest of the cell cycle would be expected from an EGFR inhibitor, since the progression of $\mathrm{G}_{1}$ to $\mathrm{S}$ phase is mainly dependent on mitogenic signals and the transcription of the cyclin D1 gene is promoted through the Ras/Raf/ERK pathway. Indeed treatment of DU145, PC3 and LNCap prostate cancer cells with the potent EGFR inhibitor Iressa ${ }^{\mathrm{TM}}$ caused $\mathrm{G}_{1}$ arrest (19). In CAL33 head and neck cancer cells treatment of Iressa also caused a $\mathrm{G}_{1}$ block (20). This supportive evidence provides more insight into the chemopreventative action of diosmetin in MDA-MB 468 cells. The dual function of luteolin as an EGFR and CDK inhibitor is mainly responsible for the $G_{1}$ arrest observed when diosmetin was incubated with MDA-MB 468 cells. However, the contribution of the metabolite D2 must not be neglected. Importantly, a $\mathrm{G}_{1}$ block was not observed in MCF$10 \mathrm{~A}$ cells, which indicates that the activation of diosmetin to luteolin is selective for the breast cancer cells.

In summary, the results presented in this study provide more insight into the chemopreventative mechanism of action of the natural flavone diosmetin. The latter is shown to inhibit proliferation of human breast cancer cells and cause a selective block in the $\mathrm{G}_{1}$ phase of the cell cycle, as a result of cytochrome P450 CYP1 bioactivation, while this effect is not observed in the cell cycle of normal breast cells. Since the conversion product of the metabolism of diosmetin, mainly responsible for the cytostastic action, is the structurally related flavone luteolin, a well known chemopreventative agent, the findings provide additional evidence on a possible tumor suppressing role of the CYP1 family enzymes.

\section{Acknowledgements}

The research was funded by De Montfort University.

\section{References}

1. Ye CL, Liu Y and Wei DZ: Antioxidant and anticancer activity of 3'-formyl-4', 6'-dihydroxy-2'-methoxy-5'-methylchalcone and (2S)-8-formyl-5-hydroxy-7-methoxy-6-methylflavanone. J Pharm Pharmacol 59: 553-559, 2007.

2. Granado-Serrano AB, Martín MA, Bravo L, Goya L and Ramos S: Quercetin induces apoptosis via caspase activation, regulation of Bcl-2, and inhibition of PI-3-kinase/Akt and ERK pathways in a human hepatoma cell line (HepG2). J Nutr 136: 2715-2721, 2006.

3. Gopalakrishnan A, Xu CJ, Nair SS, Chen C, Hebbar V and Kong AN: Modulation of activator protein-1 (AP-1) and MAPK pathway by flavonoids in human prostate cancer PC3 cells. Arch Pharmaceut Res 8: 633-644, 2006.

4. Androutsopoulos V, Arroo RR, Hall JF, Surichan S and Potter GA: Antiproliferative and cytostatic effects of the natural product eupatorin on MDA-MB 468 human breast cancer cells due to CYP1 mediated metabolism. Breast Cancer Res 10: R39, 2008 .
5. Atherton K, Mutch E and Ford D: Metabolism of the soyabean isoflavone daidzein by CYP1A2 and the extra-hepatic CYPs $1 \mathrm{~A} 1$ and $1 \mathrm{~B} 1$ affects biological activity. Biochem Pharmacol 72: 624-631, 2006.

6. Potter GA, Patterson LH, Wanogho E, Perry PJ, Butler PC, Ijaz T, Ruparelia KC, Lamb JH, Farmer PB, Stanley LA and Burke MD: The cancer preventative agent resveratrol is converted to the anticancer agent piceatannol by the cytochrome P450 enzyme CYP1B1. Br J Cancer 86: 774-778, 2002.

7. McFadyen MCE, Melvin WT and Murray GI: Cytochrome P450 enzymes: novel options for cancer therapeutics. Mol Cancer Ther 3: 363-371, 2004.

8. Kadifkova Panovska T, Kulevanova S and Stefova M: In vitro antioxidant activity of some Teucrium species (Lamiaceae). Acta Pharm 55: 207-214, 2005.

9. Meirinhos J, Silva BM, Valentão P, Seabra RM, Pereira JA, Dias A, Andrade PB and Ferreres F: Analysis and quantification of flavonoidic compounds from Portuguese olive (Olea europaea L.) leaf cultivars. Nat Prod Res 19: 189-195, 2005.

10. Androutsopoulos V, Wilsher N, Arroo RRJ and Potter GA: Bioactivation of the phytoestrogen diosmetin by CYP1 cytochromes P450. Cancer Lett 274: 54-60, 2009.

11. Browning AM, Walle UK and Walle T: Flavonoid glycosides inhibit oral cancer cell proliferation - role of cellular uptake and hydrolysis to the aglycones. J Pharm Pharmacol 57: 1037-1042, 2005.

12. Ciolino HP, Wang TTY and Yeh GC: Diosmin and diosmetin are agonists of the aryl hydrocarbon receptor that differentially affect cytochrome P450 1A1 activity. Cancer Res 58: 2754-2760, 1998.

13. Doostdar H, Burke MD and Mayer RT: Bioflavonoids: selective substrates and inhibitors for cytochrome P450 CYP1A and CYP1B1. Toxicology 144: 31-38, 2000.

14. Lim do Y, Jeong Y, Tyner AL and Park JH: Induction of cell cycle arrest and apoptosis in HT-29 human colon cancer cells by the dietary compound luteolin. Am J Physiol 292: G66-G75, 2007.

15. Casagrande F and Darbon JM: Effects of structurally related flavonoids on cell cycle progression of human melanoma cells: regulation of cyclin-dependent kinases CDK2 and CDK1. Biochem Pharmacol 61: 1205-1215, 2001.

16. Chang J, Hsu Y, Kuo P, Kuo Y, Chiang L and Lin C: Increase of $\mathrm{Bax} / \mathrm{Bcl}-\mathrm{X}_{\mathrm{L}}$ ratio and arrest of cell cycle by luteolin in immortalised human hepatoma cell line. Life Sci 76: 1883-1893, 2005.

17. Huang YT, Hwang JJ, Lee PP, Ke FC, Huang JH, Huang CJ, Kandaswami C, Middleton E and Lee MT: Effects of luteolin and quercetin, inhibitors of tyrosine kinase, on cell growth and metastasis-associated properties in A431 cells overexpressing epidermal growth factor receptor. Br J Pharmacol 128: 999-1010, 1999.

18. Squires MS, Hudson EA, Howells L, Sale S, Houghton CE, Jones JL, Fox LH, Dickens M, Prigent SA and Manson MM: Relevance of mitogen activated protein kinase (MAPK) and phosphotidylinositol-3-kinase/protein kinase B (PI3K/PKB) pathways to induction of apoptosis by curcumin in breast cells. Biochem Pharmacol 65: 361-376, 2003.

19. Sgambato A, Camerini A, Faraglia B, Ardito R, Bianchino G, Spada D, Boninsegna A, Valentini V and Cittadini A: Targeted inhibition of the epidermal growth factor receptor-tyrosine kinase by ZD1839 ('Iressa') induces cell-cycle arrest and inhibits proliferation in prostate cancer cells. J Cell Physiol 201: 97-105, 2004.

20. Magné N, Fischel JL, Tiffon C, Formento P, Dubreuil A, Renée N, Formento JL, Francoual M, Ciccolini J, Etienne MC and Milano G: Molecular mechanisms underlying the interaction between ZD1839 ('Iressa') and cisplatin/5-fluorouracil. Br J Cancer 89: 585-592, 2003. 